\title{
The Conducting Power of Gold
}

\section{JOSEPH PRIESTLEY'S EXPERIMENTS ON THE FUSION OF WIRES}

\author{
W. D. Hackmann \\ Museum of the History of Science, Oxford \\ "In this course of experiments I found myself much at a loss for a \\ sufficiently accurate method of ascertaining the difference of con- \\ ducting substances, and I wish that electricians would endeavour to \\ find such a measure."
}

On May 4th, 1766, in describing his discovery that charcoal was an excellent conductor of electricity, Joseph Priestley added the rather plaintive note recorded above.

At this time Priestley was employed as a tutor at the Warrington Academy in Lancashire, a nonconformist institution founded in 1757 "for the education of young gentlemen either for the learned professions or for business", and here he had fitted up a small laboratory, mainly for experiments in the new science of electricity. He had conceived the idea that a history of experimental philosophy was one of the great needs of the time, and while he realised that this would be an immense undertaking he thought that if he made a start with electricity others might do the same for other subjects. To further this idea he sought an introduction to John Canton, a physicist and schoolmaster in London-and a Fellow of the

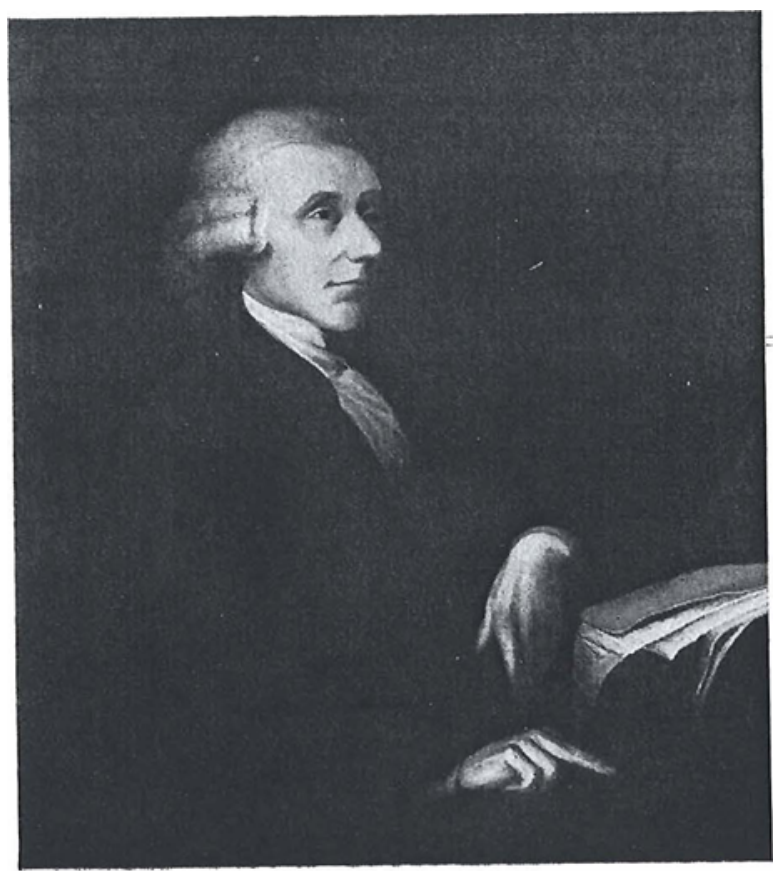

Royal Society-who had carried out original work in electricity. In December 1765 Priestley was received by Canton, remained as a guest over Christmas, and was introduced by him to, among others, Benjamin Franklin, then in London on behalf of the Government of Pennsylvania. He described his proposed history to Franklin and was given every encouragement, while Franklin also suggested a number of electrical experiments. One of these was concerned with the determination of the conducting power of different metals by passing the same discharge through wires of the same size and observing the different lengths that would be melted. (Franklin was, of course, interested in finding the most suitable metal for his lightning conductors.)

Priestley's main reason for writing a history of electricity was his interest in compiling a complete history of experimental philosophy as a demonstra-
Joseph Priestley

1733-1804,

Pioneer in education methods, religious leader, champion of political freedom and at the same time a skilled experimenter in physics and chemistry, Priestley achieved a great reputation among scientists and politicians both in Britain and in Europe. His "History of Electricity", first published in 1767, drew together the electrical researches of the period, included many original experiments, and greatly influenced the development of the subject during the remainder of the eighteenth century

From the portrait painted by Henry Fuseli, by courtesy of the Dr. Williams Library 
XIV. EXPERIMENTS INTENDED TO AgCERTAIN THE DIFFERENCE IN THE CONDUCTING POWER OF DIFRERENT METALS.

IN a converfation I once had with Dr. Franklin, Mr Canton, and Dr. Price, I remember afking whether it was probable that there was any-difference in the conducting power of different metals; and if there was, whether it was poffible to afcertain that difference? I have fince endeavoured to carry into execution a fcheme propofed by Dr. Franklin, viz. tranfmitting the fame explofion of the bittery through two wires at the fame time, of two different metals, and of tite fame thicknefs. They were hroked one to the other, and held faft in hand vifes, after they were meafured with a pair of compafies to exactly the fame length. The experiments were much more pleafing and fatisfactory than I expected, but the refult by no means correfponded to my ideas a priori.

I FIRsT joined a piece of iron wire, and a piece of copper wire. The explofion totally difperfed the iron, and left the copper untouched. The brat's likewife difappeared when joined with the copper, and the iron when joined with the brafs.

So far the experiments were ${ }^{\circ}$ extremely eafy; a fingle charge of the battery fufficing to determine the difference between any two; but when I came to compare the more perfeet metals, I found much more difficulty, and was obliged to try four or five charges of the battery upon every two: for, their conducting powers being nearly the fame, 1 either made the charge too high, and difperfed them both; or too low, and touched ntither of them. At length, I happened to htt upon fuch charges, that the copper vanilhed, and left both the filver and the gold; and the gold remained when the filver was difperfed.

From thefe experiments it is eafy to fettle the order in which the metals above mentioned are to be ranked, with refpect to the power of electricity to melt them. It is as follows. Iron, brafs, copper, filver, gold.

Extracts from the "History of Electricity" descrilling Priestley's attempts to determine the relative conducting power of metals by passing the electric discharge through two wires, at the same time, of two different metals hooked one to the other. "The experiments were much more pleasing and satisfactory than I expected, but the result by no means corresponded to my ideas a priori." But some of his findings were surprisingly accurate. He decided, for example, that lead, tin and iron were the worst conductors while brass, copper, sitver and gold were the best tion of the power of Man's rational thought and of the greatness of the Creator. He did not complete this immense task, and his only other work in this proposed series was The History and Present State of Discoveries relating to Vision, Light and Colours which was published in 1772. Thereafter he devoted most of his time to his chemical studies. In this field his greatest achievement was of course his independent discovery of "dephlogisticated air" or oxygen.

On his return to Warrington, Priestley immediately began to compile his history, but in the course of his writing he began to repeat many of the experiments he was describing and then to devise his own experiments. These very quickly secured him election to the Royal Society-in June 1766-and by the end of that year he had completed the book. Published first in the autumn of 1767 , it ran to nearly a quarter of a million words, some quarter of the total comprising accounts of his own experiments. Its full title was The History and Present State of Electricity, with Original Experiments, and it had a tremendous influence on the development of the study of electricity during the remaining part of the eighteenth century. It also gave a good account of the development of the electrostatic generator.

Priestley was greatly interested in designing an electrical machine that was cheap and simple and yet very efficient. The first machine was one to be used on a table, but he did not find it portable enough, and in the second edition of his History, published in 1769 , he described a much more portable machine. It consisted of a glass globe rubbed at its base by a cushion made of a hollow piece of copper filled with horse-hair and covered with "basil-skin" (tanned sheepskin), and was insulated by a glass disc below the globe. The hollow pear-shaped copper prime conductor received its electric charge through a long bent rod of soft brass, terminating in pointed wires which swept lightly the surface of the globe. It is not known how many of these generators were made, but it became quite a little family enterprise, involiving his brother Timothy-a Calvinist minister in Manchester-who turned the wooden tripod legs, saw to the locally made brass work, and helped with their assembly. The importance of the development of these generators in the history of electricity cannot be overemphasised. Experiments on the fusion of gold and other metals were made possible by the discovery of the Leyden jar in 1745 and then by the development of increasingly sophisticated generators which could charge the powerful batteries of jars.

Priestley's fusion experiments were very carefully executed, and resulted in the first attempted ordering of the metals according to their conducting power. He took two wires of the same length and diameter but of different metals, hooked them together, 
ensured good electrical contact by stretching them tightly with hand vices, and passed a powerful electric discharge through them, using his battery of Leyden jars. The wire that fused he considered to be the worse conductor of the pair.

"From these experiments", he wrote, "it is easy to settle the order in which the metals above mentioned are to be ranked with respect to the power of electricity to melt them. It is as follows. Iron, brass, copper, silver, gold."

It must be remembered that Priestley's experiments were conducted long before the existence of any sophisticated means of measuring the charge produced by his electric generator. His conclusion that gold was the best conductor of electricity is not of course in accord with modern results, although it should be added that Priestley had expected that gold would have melted before silver. The factors of importance in using the fusion method as a technique for determining the conductivity of gold or of any other metal are of course resistance, specific heat and melting point. The concept of conductivity (the reciprocal of resistance) dates back to the eighteenth century work on the lightning conductor, although the formulation of "resistance" had to wait until Ohm's work of 1826 . The concept of specific heat came later, formulated by both Joseph Black, whose results were published posthumously in 1803, and independently by Johan Carl Wilke in 1781. Priestley was shrewd enough, however, to conclude that before any use could be made of his fusion experiments in the determination of the relative conducting power of the metals, the order in which they melted with "common heat" would have to be compared with the order in which they melted with the "electrical explosion".

Priestley's fusion experiments had another important outcome. They led to his conclusion that the "force of the electrical explosion was directly proportional to the length of wire fused and to the square of its diameter". This gave "electricians" the idea of using the rate of fusion of a standard wire as

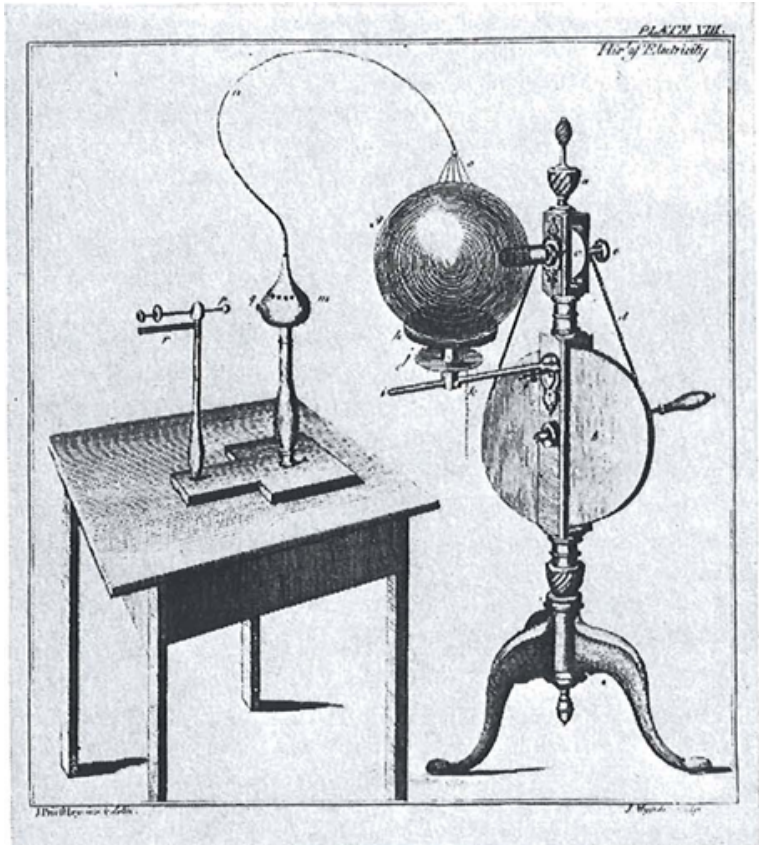

A drawing, made by Priestley himself, of his preferred design of electric generator. The glass globe was rubbed at its base by a hollow piece of copper covered with sheepskin and was insulated by a glass dise underneath. The hollow pearshaped copper conductor received its charge through a long bent rod of soft brass, terminating in pointed wires in contact with the surface of the globe

a measure of charge, and eventually led to the formulation of the law of fusion by John Cuthbertson in Nicholson's fournal in 1799:

"that double quantities of electric fluid, in the form of a discharge, will melt four times the length of wire of a certain diameter. . ..".

He did not realise the significance of this conclusion for he thought that it only held for static and not for current electricity, and it was Sir Snow Harris who firmly established this law in the 1830s and on it based his "electro-thermometer" which measured current by the heat evolved in a standard one-inch platinum wire. The "electro-thermometer" was the prototype of a whole range of similar instruments; including the modern hot-wire ammeter.

COLD is truly incorruptible, abundantly expansive, can neither be diminished $\checkmark$ by fire nor broken by blows; it is undefiled, for it suffers no rust, hence it is the protector of all other metals. Does not gold signify abundant and unimpeachable trust, constant worth in adversity and the virtue of moderation in prosperity?

From a letter written in 1166 while in exile in France
JOHN OF SALISBURY

Secretary to Thomas à Becket 